\title{
The Choices of Internationalization Strategy of Chinese Multinational Enterprises Under the Background of One Belt and One Road
}

\author{
-Take Geely for example
}

\author{
Chengjun $\mathrm{Lu}$ \\ Yunnan University of Finance and \\ Economics \\ Kunming, China \\ 1531593235@qq.com
}

\author{
Xiang Wang* \\ Yunnan University of Finance and \\ Economics \\ Kunming, China
}

\author{
Xuan Luo \\ Yunnan University of Finance and \\ Economics \\ Kunming, China \\ 506857056@qq.com
}

\begin{abstract}
In the continuous "going out" campaigns and actions of China's independent automobile brands, Geely group has continuously expanded its travel territory by acquiring Volvo, taking a stake in Daimler and establishing Lynk \& Co brand, thus becoming a leader in the industry. How to meet challenges and seize opportunities in the fierce international competition? Taking Geely automobile as the research object, this paper analyzes its internationalization operation process, path and successful experience,provides countermeasures and suggestions for deepening the international operation of Geely automobile, and provides effective reference for Chinese automobile enterprises to enter overseas markets and enhance their international competitiveness.
\end{abstract}

Keywords: internationalization strategy, multinational enterprises, Geely

\section{INTRODUCTION}

In terms of the definition of enterprise strategy, Ansoff [1] defines enterprise strategy as the main line of interrelated and common operation between enterprise market and operation and products, which determines the basic nature of the business that an enterprise is engaged in. In terms of the definition of enterprise internationalization, Johanson and Mattsson[2] define enterprise internationalization as "the process of establishing, forming and developing the network relationship between enterprises in the whole network of international market". In the book transnational direct investment and internationalization strategy of Chinese enterprises, domestic scholar Yafei Song[3] defined internationalization strategy as: enterprises carry out transnational sales, production, research and development and other transnational business activities , while owning and controlling marketing, production or service facilities abroad.

To sum up, the internationalization strategy of an enterprise is a set of systems and strategies designed by an enterprise for better growth, continuous improvement of its competitiveness, and improvement of its endurance to the environment, which is also the development plan set in the internationalization management. On the macro level, the internationalization strategy of an enterprise is reflected in the development strategy of the enterprise, including three levels of the company, business units and functions, while on the micro level, it involves internationalization motivation, market entry mode and operation strategy selection.

In terms of internationalization strategy, many domestic and foreign scholars also analyze internationalization strategy from different perspectives. Porter[4] once believed that business layer strategies are generally divided into three types: low-cost, differentiation and target clustering strategies. Lowcost strategy is mainly to establish a cost structure to provide products and services at a lower unit cost than competitors to gain competitive advantage. Differentiation strategy aims to help enterprises create a product that is different or unique from competitors in important aspects to highlight the competitive advantage. The target agglomeration strategy is mainly to serve a specific market segment, seeking low cost or differentiation within the market. Porter believes that if you want to help enterprises maximize their goals, you must choose one strategy to carry out effectively. Low cost and differentiation cannot coexist, otherwise poor performance will be generated. In Porter's view, there is a big difference in the strategic framework between low cost and differentiation, and the implementation of either requires sufficient resources.

According to the internationalization of enterprise strategy management, enterprise internationalization strategy also can be divided into domestic internationalization strategy and extroverted internationalization strategy, in terms of extroverted internationalization strategy definition, Jiangfan Li , Naihua $\mathrm{Gu}[5]$ defined as: outward internationalization is refers to the enterprise within the scope of international funding and a series of factors of production, products, technology, and then in the production process to realize internationalization. Introverted internationalization refers to the fact that the operation basis of an enterprise is in the domestic market, and the competitiveness of the enterprise can be improved by introducing products, management experience, technology and other production resources from the international market.

*Corresponding author 
Domestic and foreign scholars have drawn conclusions from multiple perspectives and made great contributions to the research of enterprises' foreign investment. In these studies, foreign scholars are more inclined to theoretical analysis, while Chinese scholars are more focused on empirical research. Different scholars at home and abroad have different research emphases and research angles, and they all have certain relative limitations. However, in the study of the internationalization of Chinese enterprises, there are not many cases to analyze.

\section{EASE OF USE THE TYPE OF ENTERPRISE INTERNATIONALIZATION STRATEGY}

Since enterprise internationalization requires enterprises to manage internationalization process at the strategic level, an important branch of enterprise internationalization research is to study enterprise internationalization strategy. Published in 1962, the United States economic historian chandler "strategy and structure of each historical stages in the development of industrial enterprises", put forward "the company's strategy will determine its structure", "enterprise follow strategy", based on the characteristics of different enterprise strategy and implementation stage, from the cost control of the enterprise and enterprise's integration in the international market point of view, enterprise internationalization strategy can be divided into strategy, strategy of multinational, global strategy and international strategy.

\section{A. International Strategy}

Enterprises achieve their profit targets by transferring products to foreign markets that lack such products. Because such enterprises always maintain control over marketing strategies and products, it is difficult to expand the scale of internationalization.

\section{B. Multinational Strategy}

Enterprises implement transnational strategies tend to transfer their products to foreign markets, but enterprises tend to pay attention to different market demands, constantly adjust their marketing mix strategies according to market changes, and try to adapt to different countries with different market demands.

\section{Global Strategy}

Companies focus their production, research and development, and marketing categories on the most profitable areas. They will adjust production and sales timely and dynamically according to the actual situation in different regions, and tend to sell products globally

\section{Transnational Strategy}

The flow of enterprise operating resources should not only be a one-way process from domestic company to overseas company, but also from one subsidiary to another. It emphasizes that the transfer of enterprise operating resources should be realized on a global scale.

\section{OVERVIEW OF GEELY GROUP}

Geely auto holdings LTD. is listed on the Hong Kong stock exchange, specializing in manufacturing and distributing automobiles and auto parts.Since it entered the field of sedan in 1997 , it has become one of the major manufacturers of China's independent automobile brands. The development path of Geely auto can be divided into four stages. From 1986 to 2000, Geely auto entered the auto industry in exploration; From 2001 to 2009, Geely auto steadily developed in China and implemented the internationalization strategy for the international market. From 2010 to 2017, Geely auto built its brand image through a series of important acquisitions; In 2018, Geely auto bought a stake in Daimler and went to the high-end market.

Table 1 shows the sales volume and ranking of the top 15 automobile companies in China in 2017 and 2018. It can be clearly seen that the annual sales volume of saic-volkswagen, faw-volkswagen and saic-gm in 2018 were respectively 2019430, 1991788 and 1749496, occupying the top three sales volume of automobile manufacturers in China for two consecutive years. And Geely auto rose from the sixth place in 2017 to the fourth place in 2018 , with a strong sales growth of $22.47 \%$ year-on-year.

Table 1 Sales volume and ranking of the top 15 automobile companies in China in 2017 and 2018

\begin{tabular}{|c|c|c|c|c|}
\hline Manufacturer & $\begin{array}{c}\text { Ranking } \\
\text { in } 2018\end{array}$ & $\begin{array}{c}\text { Sales in } \\
2018\end{array}$ & $\begin{array}{c}\text { Ranking } \\
\text { in 2017 }\end{array}$ & $\begin{array}{c}\text { Sales in } \\
2017\end{array}$ \\
\hline $\begin{array}{c}\text { Shanghai } \\
\text { Volkswagen }\end{array}$ & 1 & 2019430 & 1 & 2046377 \\
\hline $\begin{array}{c}\text { FAW- } \\
\text { Volkswagen }\end{array}$ & 2 & 1991788 & 2 & 1950088 \\
\hline $\begin{array}{c}\text { Shanghai } \\
\text { General } \\
\text { Motors }\end{array}$ & 3 & 1749496 & 3 & 1906174 \\
\hline $\begin{array}{c}\text { Geely } \\
\text { Automobile }\end{array}$ & 4 & 1473305 & 6 & 1202963 \\
\hline $\begin{array}{c}\text { SAIC-GM- } \\
\text { Wuling }\end{array}$ & 5 & 1316186 & 4 & 1532472 \\
\hline $\begin{array}{c}\text { Dongfeng } \\
\text { Nissan }\end{array}$ & 6 & 1300042 & 5 & 1262891 \\
\hline $\begin{array}{c}\text { Great Wall } \\
\text { Automobile }\end{array}$ & 7 & 881539 & 8 & 922393 \\
\hline $\begin{array}{c}\text { Chana } \\
\text { Automobile }\end{array}$ & 8 & 826432 & 7 & 1039476 \\
\hline $\begin{array}{c}\text { Beijing } \\
\text { Hyundai }\end{array}$ & 9 & 746090 & 9 & 816015 \\
\hline $\begin{array}{c}\text { Guangqi } \\
\text { Honda }\end{array}$ & 10 & 735410 & 10 & 729529 \\
\hline FAW Toyota & 11 & 716392 & 12 & 702215 \\
\hline $\begin{array}{c}\text { Dongfeng } \\
\text { Honda }\end{array}$ & 12 & 697015 & 11 & 727026 \\
\hline $\begin{array}{c}\text { SAIC } \\
\text { Passenger Car }\end{array}$ & 13 & 655999 & 14 & 507768 \\
\hline GAC Toyota & 14 & 580337 & 15 & 440390 \\
\hline Trumpchi & 15 & 535168 & 13 & 508586 \\
\hline
\end{tabular}


Source: China association of automobile manufacturers.

Geely owns Geely Auto, Lynk \& Co Auto, Remote New Energy Commercial Vehicle, Volvo auto, Proton Auto and other brands. Geely group has formulated the "20200" strategy, aiming to achieve the production and sales of 2 million cars by 2020 and become a respected automobile brand.

\section{MotivationS of Geely group's international operation}

\section{A. Expanding Market}

As one of the pillar industries of national economy, automobile industry has the characteristics of strong correlation, long industrial chain and great driving force. For developed countries in the primary market, the automobile industry is the core industry related to the national economy and people's livelihood. The implementation of international operation enables them to find new customers in the international market and effectively expand the market scale[6]. At present, due to the implementation of trade protectionism on the automobile industry in developed countries, various trade barriers have become the threshold of China's automobile export. By overseas investment and multinational management can effectively avoid the host countries fom setting up trade barriers, obtaining foreign sales platform and information network, prompted the internalization of international trade, tariff policy, tax policy and the relevant countries both restrictive role of exchange rate policy has been weaken in varying degrees, thus reducing the internationalization, can more effectively to expand market share.

\section{B. Integration Of Resources}

Influenced by the natural environment, economic development level, market demand and other related factors, the factors of production exist heterogeneity among different regions. Under the regulation of the market, various resources circulate freely in the global scope, and the production activities of any enterprise should be included in every link of the value chain. Through overseas investment, Geely auto can reduce operating costs and seek optimal resource allocation in both domestic and international markets, thus seeking a foothold in the international market. Geely auto chooses to build factories in foreign regions to play the advantages of the vertically integrated development model, shorten the production and r\&d cycle, eliminate intermediate links, and give play to the advantages of cost and late-development.

\section{Building a brand}

Implementing the strategy of international growth and acquiring foreign brands is the shortcut for rapid progress of automobile enterprises. In the early stage of Geely's development, it implemented the low-price strategy, giving customers the impression of "low-quality and low-end cars". The acquisition of international well-known automobile brands and other international strategies will help Geely auto to improve its brand disadvantages and overcome the bottleneck of brand development. As the international market, led by Europe and the United States, has become increasingly saturated in recent years, many auto giants have turned their attention to the Chinese market. The competition in the automobile industry is not only about technology, but also about brand. If European and American automobile companies with obvious brand advantages enter the Chinese market, they will bring greater competitive pressure to China's independent automobile brands. Therefore, it is particularly important to enhance the brand positioning and build a brand with unique brand value.

\section{DEVELOPMENT PROCESS OF GEELY GROUP'S} INTERNATIONAL OPERATION

Geely group has developed into a world top 500 famous enterprise.Along the way, Geely has experienced four stages of internationalization strategy.

\section{A. Foundation Stage}

Competition in the domestic auto market is fierce. At the initial stage of its establishment, Geely group positioned itself at the domestic low-end auto market and determined to build good cars that people can afford. Faced with the urgent car demand of Chinese people at that time and the low income of most people, Geely's low-price marketing strategy made Geely auto stand out and gradually grow stronger. At the same time, Geely actively operated listing and listed in Hong Kong in 2005. The successful listing brought Geely group abundant capital. Sufficient working capital has laid a solid foundation for the expansion of Geely's subsequent enterprise scale and cross-border mergers and acquisitions.

\section{B. Market Acceptance Stage}

At the initial stage of internationalization, Geely group entered the Middle East, north Africa and other third world countries in the form of export trade. Compared with developed countries in Europe and the United States, this region has relatively low requirements for automobile energy saving, emission reduction, safety and other certification systems. Meanwhile, this region has considerable automobile demand, but the automobile industry is not developed and there is no fierce market competition. Thanks to the right location choice, the export volume of Geely auto has grown rapidly, and in 2012, the export volume has exceeded 100,000. In the early stage of transnational operation, the rapid growth of Geely auto export volume meant that the international market recognized Geely's brand, and Geely group's goglobal strategy achieved initial success.

\section{Overseas Plant Construction and Acquisition Stage}

Geely group was not satisfied with the success of the export model, but to speed up the pace of transformation, through factories overseas or acquisition directly into the multinational business location. In May 2007, Geely and IGC group signed the cooperative project agreement of Geely ck1ckd to build a joint venture factory in Jakarta, capital of Indonesia for local production, assembly and marketing. In order to enter relevant locations of cis, Geely built assembly plants in Ukraine and Russia. In 2012, Geely group set up a factory to assemble cars in Egypt. So far, Geely has gradually formed a global assembly plant ecological chain. In addition to building factories overseas, Geely group also enters the market through cross-border mergers and acquisitions of foreign 
companies, thereby improving the auto industry chain and learning advanced technologies and management models.

\section{Implementing Brand Strategy Stage}

China's private cars have always been branded with a lowend brand. The improvement of automobile brand influence can help enterprises seize the high-end market and increase their market share. Geely's acquisition of Volvo cars in 2010 was an important step in its brand strategy. In order to fully integrate the resources of Volvo and Geely, Geely group built a European r\&d center in Sweden. Geely has basically completed the layout of global research and development and global production, and is gradually moving forward to become a world-renowned automobile manufacturer.

According to the data published on Geely's official website, this paper sorted out the major events of Geely group's international operation, as shown in table 2 .

Table 2 Major events of Geely's international operation

\begin{tabular}{|c|c|}
\hline Time & Event \\
\hline August,2003 & The first Geely automobile went abroad. \\
\hline May,2005 & Geely is listed in Hong Kong. \\
\hline October,2006 & $\begin{array}{l}\text { Geely bought a } 19.97 \% \text { stake in } \\
\text { MengTong. }\end{array}$ \\
\hline January,2007 & $\begin{array}{l}\text { The first Geely free ship rolled off the } \\
\text { production line at the SKD factory in } \\
\text { Ukraine.Geely auto realized overseas } \\
\text { production. }\end{array}$ \\
\hline March,2009 & $\begin{array}{l}\text { Geely bought Australia's DSI (the } \\
\text { world's second largest automatic } \\
\text { transmission company). }\end{array}$ \\
\hline March,2010 & $\begin{array}{l}\text { Geely acquired a } 100 \% \text { stake in Volvo } \\
\text { cars and related assets. }\end{array}$ \\
\hline February,2013 & $\begin{array}{c}\text { Geely fully acquired the business and } \\
\text { core assets of Britain's MengTong } \\
\text { holdings. }\end{array}$ \\
\hline February,2013 & $\begin{array}{l}\text { Geely announced the establishment of a } \\
\text { European research and development } \\
\text { center in Gothenburg. }\end{array}$ \\
\hline July,2015 & $\begin{array}{l}\text { Geely acquired Carbon Recycling } \\
\text { International. }\end{array}$ \\
\hline June, 2017 & $\begin{array}{c}\text { eely acquired a } 49.9 \% \text { stake in Proton } \\
\text { and a } 51 \% \text { stake in Lutz. }\end{array}$ \\
\hline November,2017 & $\begin{array}{l}\text { Geely acquired all the operations and } \\
\text { assets of Pacific Power. }\end{array}$ \\
\hline February,2018 & $\begin{array}{l}\text { Geely acquired a } 9.69 \% \text { stake in } \\
\text { Daimler. }\end{array}$ \\
\hline
\end{tabular}

Source: Sorted according to the official website of Geely.

\section{ANALYSIS OF GEELY GROUP'S INTERNATIONAL OPERATION PATH}

\section{A. Original Equipment Manufacturing}

At the initial stage, Geely acquired low-end technology of automobile manufacturing by building cars in shell, imitating cars and cooperating with others. This stage is the original manufacturing stage of Geely group. In the 1990s, the domestic automobile industry was dominated by joint ventures between state-owned automobile enterprises and automobile enterprises in developed countries. Faced with such a highly competitive market, Geely group at that time sought to survive by actively embedding itself into the value chain. At the beginning, the imitation and cooperation with foreign auto companies only enabled Geely group to acquire certain car manufacturing technology, but the active embedding in the lower end of the value chain laid a certain foundation for the future internationalization of Geely group.

\section{B. Global Marketing Network}

By exporting and investing overseas, Geely has built a global marketing network.

Based on the principle of selecting countries with close psychological distance with their own countries as destination countries for initial export, Geely group mainly exported to the Middle East and Africa in the initial stage of internationalization. At the same time, these places are relatively backward, with a large market and little competition, few cars in the society, and relatively low requirements on environmental protection. In this stage, Geely trained a large number of marketing personnel from exporting countries and better integrated local culture and customs, which played a very important role in Geely's development in the Middle East and north Africa. Opening the Middle East and north Africa market is a successful start for Geely group's export, and also lays a solid foundation for Geely's overseas operations in the future.

Through overseas plant construction, Geely group has successfully opened southeast Asian markets, eastern European and Russian markets, north African and middle eastern markets Brazil and Argentina markets, and established production and assembly plants worldwide.

In 2013, Geely group acquired British manganese copper, but before that, there was no profit in British manganese copper for a long time. Geely group acquired British manganese copper out of consideration of the brand value, market and marketing channel of British manganese copper. At the same time, Geely group entered the domestic taxi industry from now on, developed vehicles with better performance and improved environmental performance.As a result,it realized the international production

With the gradual increase of China's national economic capacity, after Geely group acquired DSI, customers' demand for automatic transmission cars continued to increase. But before this our country own brand automobile had no ability to manufacture automatic transmission. This acquisition has enabled Geely to take a leading position in the production and manufacturing of automatic transmissions and improved Geely group's product strategy.Automobile industry is a representative capital and technology-intensive industry, and technology and talents play a huge role in the automobile industry. This merger and acquisition enabled Geely group to break the monopoly of core technologies of automobile 
enterprises in developed countries and greatly enhance Geely group's strength in overseas markets.

\section{Private Brand Manufacturing}

The acquisition of Volvo has transformed the Geely auto brand. Geely group's successful acquisition of Australia's DSI company has improved its product strategy and absorbed the technology of automatic transmission manufacturing and research and development, making Geely group's influence in the global automobile industry bigger.The acquisition of Geely group has obtained the most core capital of the auto industry, such as technology, talents and brands, making it possible for China's auto industry to develop into the international high-end market and greatly promoting Geely group's position in the value chain. This acquisition enabled Geely group not only to obtain the core technology of automatic transmission production of Australia's DSI company and realized the technology upgrade, but also to acquire Volvo's global customers and the entire sales network, expand Geely's market capacity and make a great contribution to the improvement of vehicle production capacity.In 2011, Geely group exported 5\% of its vehicles. If the acquisition of DSI allowed Geely to break the foreign monopoly on high-end technology in auto production, then the acquisition of Volvo helped Geely become one of the world's high-end auto brands. The acquisition of Volvo has greatly promoted the internationalization of Geely group and its climb up the global value chain. Because the acquisition of Volvo has greatly promoted the promotion of Geely's brand and provided the possibility for Geely to realize its own brand independence became possible.

\section{GEELY'S SUCCESSFUL EXPERIENCE}

\section{A. Geely Has Successfully Implemented Its Global Development Strategy.}

Based on its own reality, Geely conformed to the trend of economic globalization.In the face of fierce competition from global companies, it also learned the global business model and strategic thinking mode of global companies.By actively adjusting its development strategy and continuously absorbing and integrating global resources, Geely has continuously transformed itself into a global company in the way of utilizing global ready-made technologies, patents and even brands.

\section{B. Geely Has Successfully Achieved A Development Path That combined Endogenous Organic Growth With Epitaxial Growth.}

On the one hand, Geely is constantly looking for suitable targets in the global market to achieve extensive growth. On the other hand, it constantly improved its technological innovation ability and promoted its organic growth with the help of the acquired company's technical ability.

By acquiring Australia's DSI, Geely acquired key technology for automatic transmissions; Through the acquisition of Volvo, Geely fully understood, participated in and mastered the research and development of Volvo and the sharing of the research and development database, rapidly improved the research and development ability of Geely automobile and brought Geely to a new height. Through the acquisition of British electric car company,it layout new energy field;It acquired Terrafugia flying cars, an American company, to lay out forward-looking technology.This extensive growth mode enabled Geely to quickly learn and master the experience which greatly promoted Geely's endogenous organic growth.

\section{Geely Has Achieved A Global Layout Of The Entire Value Chain.}

In terms of global R\&D layout, cooperation between Geely and Volvo in the field of R\&D has led to the establishment of the European R\&D center of Geely holding group in gothenburg, Sweden, to develop and design products to meet the future market demand of Geely auto and Volvo auto. This enabled Geely to truly integrate into the internationalized car r\&d cycle system. And at the same time, it was also an important strategy for Geely to integrate into and create a global R\&D system.In terms of global procurement layout, Geely auto had a broader global procurement scope and gained opportunities to cooperate with top global suppliers.In terms of global manufacturing layout, Geely was also actively promoting the construction of manufacturing bases overseas.In the future, Geely will establish clear production capacity and investment plans in eastern Europe, central and Central America, South America, Middle East and North Africa.In terms of global sales, Geely auto mainly exported to nearly 60 countries and regions in eastern Europe, the Middle East, Africa, southeast Asia, Oceania, central and South America.It has established more than 400 sales and service outlets overseas.

\section{Geely Has always insisted on independent innovation in open cooperation.}

In the era of economic globalization, enterprises should have new ideas and new understanding of independent innovation.That is to say, the independent innovation of enterprises should start from enhancing the innovation ability of enterprises, including original innovation, integrated innovation and introduction, digestion, absorption and reinnovation. We should emphasize the spirit of continuous selfimprovement and lead the process of innovation instead of making innovations by ourselves behind closed doors.Geely improved the company's independent innovation ability through open cooperation, explored new models of independent innovation in international cooperation, and promoted the improvement of enterprises' independent innovation ability.

\section{E. Geely Has Geely attaches great importance to compliance operation in globalization.}

In today's increasingly strengthened global regulation, global companies have greatly changed the competition rules of global enterprises by strengthening compliance operations, thus bringing about new rules of global competition.In 2014, Geely officially launched the company's compliance system construction project.As for the construction of compliance culture, chairman li shufu believes that compliance is the premise of sustainable development of enterprises, the key to 
global economic interdependence and competition in accordance with the law, and the rules of the game for the continuous progress of human economy and society. Compliance is not only the basic way for enterprises to survive, but also the basic premise for enterprises to assume social responsibilities. It is also an important means for Geely to establish a global integrated corporate culture.

\section{CONCLUSION}

The success of geely group's internationalization strategy has caused domestic people to think. At present, Chinese enterprises are faced with the crisis of the ever-changing new situation. Therefore, it is urgent to explore the strategic guidelines and strategies suitable for enterprises themselves.

\section{A. Adhere to the path of international operation.}

With the continuous opening of the country and the entry of foreign capital, it is a wise choice to go international.

\section{B. Strive to cultivate and develop the core competitiveness of the enterprise.}

Lack of core competitiveness is a prominent problem faced by Chinese enterprises. To solve this problem, two points should be achieved: first, improve the management ability of enterprises and promote the adjustment of organizational structure of enterprise groups. The second is to actively promote enterprise informatization and promote the organic integration of core competitiveness and information technology.

\section{Strive to cultivate and give full play to comparative advantages.}

Through deepening reform, expanding opening up, promoting reform through opening up, transforming resource advantages into competitive advantages and potential advantages into real advantages. Improve the efficiency of domestic resources allocation through market forces and attract international economic resources by creating a favorable market environment.

\section{Carry out cooperation and competition, with special emphasis on cooperation between domestic and foreign enterprises.}

The root cause of domestic and overseas cooperation lies in unbalanced economic development. Through economic cooperation, local enterprises can exchange what they have and draw on each other's strengths, which will promote the development and growth of enterprises, enhance their competitiveness and realize the goal of common development. Therefore, enterprises can innovate management and operation by means of asset reorganization, transnational cooperation and e-commerce operation according to their own characteristics.

\section{REFERENCES}

[1] Ansoff H.I. "Corporate strategy: An Analytic Approach to Business Policy for Growth and Expansion". Penguin boobs, vol.48, pp. 126135,May 1970.

[2] Johansson J, Mattson L G, Hood N, et al. "Strategies in Global Competition".Strategies in global competition, vol.14,pp. 75-81,March 1988.

[3] Yafei Song, Transnational direct investment and internationalization strategy of Chinese enterprises: China financial and economic publishing house, 2010.

[4] Michael Porter, National competitive advantage, Citic publishing house, 2007

[5] Jiangfan Li, Naihua Gu, "From inward internationalization to outward internationalization: the path of internationalization for pearl river delta state-owned service enterprises under CEPA", Southern economics, No.3, 2004

[6] Fang T,Chimenson D. The Internationalization of Chinese Firms and Negative Media Coverage: The Case of Geely' s Acquisition of Volvo Cars.J.Thunderbird International Business Review, vol.59,pp.483502,April 2017 